Перспективи подальших досліджень полягають в розробленні моделі формування графічних умінь в учнів початкових класів на уроках трудового навчання.

\title{
Лiтература
}

1. Андрианов П.Н. Развитие технического творчества в трудовом обучении учащихся общеобразовательной школы / П.Н. Андрианов. - М., 1985. - 131 с.

2. Гриценко Н. Інтеграція предметів природничо-математичного циклу в умовах профільного навчання / Н. Гриценко // Завуч. - 2007. - №21 (липень). - С. 25-27.

3. Долбилин Н.П. О курсе наглядной геометрии в младших классах / Н.П. Долбилин, Н.Ф.Шарыгин // Математика в школе. - 1990. - №6. - С. 19-21.

4. Програма для середньої загальноосвітньої школи 1-4 класи. - К. : Початкова школа, 2006. $-432 \mathrm{c}$.

5. Сергієнко В. Науково-практичне місце інтеграції та інтеграційні особливості навчального процесу в ліцеї економічного профілю / В. Сергієнко // Завуч. - 2007. - №21 (липень). - С. 6-7.

Стаття надійшла до редакції 25.05.2012 p.

УДК $373.5: 37$

\author{
A.I. Терещук, \\ докторант, \\ Уманський ДПУ \\ імені Павла Тичини
}

\section{ПРОБЛЕМИ ПРОФЕСІЙНОЇ ОРІЄНТАЦІЇ ТА САМОВИЗНАЧЕННЯ УЧНІВ СТАРШОЇ ШКОЛИ}

Терешук А. І. Проблеми професійної орієнтації та самовизначення учнів старшої школи.

У статті розглянуто проблеми професійної орієнтаиї учнів та професійного самовизначення старшокласників, проаналізовано особливості традиційної системи профорієнтації у зв'язку з пошуком нових шляхів розв'язку проблеми.

Ключові слова: професійна орієнтація, самовизначення, соиіальне замовлення, індивідуальні потреби особистості, діяльнісний підхід.

Терещук А. И. Проблемь профессиональной ориентащии и самоопределения учащихся старшей школь.

В статье рассмотрены проблемы профессиональной ориентации учашихся $и$ профессионального самоопределения старшеклассников, проанализированы особенности традиционной системы профориентации в связи с поиском новых способов решения проблемы.

Ключевые слова: профессиональная ориентация, самоопределение, сочиальный заказ, индивидуальные потребности личности, деятельный подход.

Tereshuk A. I. Problems professionally orientation and self high school students.

The problems of professional orientation of students and professional self seniors, analyzes the features of the traditional system of vocational guidance in the search for new ways of solving problems.

Key words: professional orientation, self-determination, social order, the individual needs of the individual, active approach.

Постановка проблеми. Загальним теоретичним проблемам формування готовності до професійного самовизначення у майбутній трудовій діяльності присвячено ряд досліджень К. Абульханової-Славської, Ю. Алферова, С. Батишева, Л. Буєвої, Ф. Іващенка, С. Клімова, Г. Костюка, В. Моляко, В. Полякова, М. Скаткіна, В. Чебишевої та інших. 
Проблеми методики профорієнтаційної роботи з учнівською молоддю, розкриваються в роботах Д. Закатнова, С. Клімова, Г. Левченка, В. Мадзігона, Є. Павлютенкова, М. Піддячого, А. Сазонова, В. Сидоренка, В. Ситмоненка, М. Тименка, Д. Тхоржевського, Б. Федоришина, С. Чистякової, М. Янцура та багатьох інших.

Аналіз наукових досліджень засвідчує, що процес формування готовності до професійного самовизначення має низку недоліків та упущень. По-перше, відсутній системний підхід у змісті профорієнтаційної роботи, що зумовлено порушеними зв'язками між різними чинниками, що впливають на професійне самовизначення старшокласника: школою, засобами масової інформації, МНВК, родиною учня, виробничими організаціями і підприємствами тощо. Подруге, недостатньо відпрацьовано систему профорієнтаційної роботи в навчально-виховних закладах, зокрема, міжшкільних навчально-виробничих комбінатах $[1$, с. 4$]$.

Метою статті є розгляд проблем, що склались у зв'язку з професійною орієнтацією молоді та відповідним професійним самовизначенням старшокласників.

Виклад основного матеріалу. Профорієнтаційній роботі у радянській загальноосвітній школі відводилась особлива роль - підготувати молодь до свідомого вибору робітничої професії. Таке завдання було підкріплене відповідними постановами ЦК КПРС та Ради Міністрів СРСР, і його актуальність пов'язували 3 тим, що виробництво характеризується значною диференціацією праці між окремими працівниками [4, с. 20].

У профорієнтаційній роботі зобов'язувались брати участь не лише освітні заклади, але й інші організації (творчі спілки, комітети преси, радіо, телебачення, промислові та сільськогосподарські міністерства тощо), як це було передбачено відповідною постановою ЦК КП України. На практиці профорієнтаційна робота проводилась переважно як профосвіта [Там само, с.21].

Як показує практичний досвід, учителі й нині застосовують такі основні форми профорієнтаційної роботи, як от: профорієнтація на уроках, коли в ході занять учитель ознайомлює учнів 3 професіями, пов'язаними 3 роботою, яку вони виконують; профорієнтація під час екскурсії на підприємство; профорієнтаційна робота на гурткових заняттях тощо.

Професійна орієнтація молоді та залучення їх до професійного самовизначення певною мірою залежить від традиційної пострадянської системи освіти, яка була орієнтованою на підготовку узагальненого ерудованого випускника школи. Водночас значну увагу приділено професійній агітації, активному залученню учнів до набуття робітничих професій. Склалися проблеми, що були зумовлені відсутністю, у вітчизняному досвіді профорієнтаційної роботи, особистісно орієнтованого підходу, що негативно впливало на реальний процес самовизначення старшокласників.

На відміну від зарубіжного досвіду де активно практикувалась спеціалізація, радянську освіту характеризувала низка особливостей, які полягали в тому, що провідним в освіті був знаннєвий підхід. За часів 
Радянського Союзу суспільству потрібні були ерудовані і «наповнені» енциклопедичними знаннями люди. За умов планового ведення господарства і колективної відповідальності за результати праці, можна було «приховати» професійну некомпетентність окремого працівника. Однак нині, нові економічні умови, у яких перебуває Україна диктують інші вимоги до підготовки фахівців. Із загальноосвітньої школи в життя має йти особистість, здатна до самостійного пошуку виду трудової діяльності, підготовлена до неперервного процесу професійного удосконалення, спрямована на постійний творчий пошук свого «Я» у власному професійному житті.

Зміст професійної орієнтації, у тому числі професійного вибору, необхідно розкривати 3 позиції розв'язання головної суперечності педагогічного процесу. Ї̈̈ визначають як співвідношення двох сторін: вимоги щодо задоволення суспільних потреб, які висуваються офіційною системою освіти (суспільне «треба»), 3 індивідуальними потребами (інтересами, цінностями) окремих учнів чи деяких їх груп (учнівське «хочу»). Велика роль у цьому процесі належить «...задаткам, уподобанням, здібностям особистості учня (індивідуальне «можу»)» $[5$, с. 19]. Варто наголосити на тому, що у вітчизняній загальноосвітній школі саме соціальне замовлення суспільства було визначальним, тоді як уподобання, і потреби учнів, особливо пов'язані 3 їх життєвими намірами, відходили на другий план. Здавалося б, що саме розумний баланс між соціальним «треба» i особистісним «хочу» міг вирівняти і гармонізувати систему профорієнтації. Натомість саме через зміщення акцентів у бік соціального замовлення та переоцінювання провідної ролі учителя у справі загальної освіти, більшість профорієнтаційних заходів набували штучного характеру.

Функціональними нині $є$ два основних напрямки в управлінні структурою профорієнтації, які склались у вітчизняній школі. Перший напрямок характеризує розвиток профорієнтації в системі загальної освіти. Як підкреслює М. Опачко, Г. Щьокін та інші, аргументи на користь цього напрямку базуються на тому, що «профорієнтаційна робота має загальноосвітню природу» $[6$, с. 110]. У межах цього напрямку сформувались й одержали свій подальший розвиток такі складники профорієнтації, як профінформація, частково профконсультація.

Другий напрямок характеризує розвиток структури профорієнтації в системі соціальних інститутів [7; 8]. Найбільша увага в цьому випадку приділяється розвитку форм і методів профконсультації, визначенню профпридатності та профадаптації. Управління системою профорієнтації здійснюється на рівні трьох основних аспектів: соціально-економічного, психолого-педагогічного, медико-біологічного. Ефективність профорієнтаційної роботи на будь-якому рівні залежить від того, настільки оптимально реалізується комплексний підхід до управління цими процесами.

Загальноприйнятий підхід у профорієнтаційній роботі науковці називають «діяльнісним» і визначають його як провідним у розв'язанні проблем профорієнтації (К. Абульханова, Г. Костюк, М. Опачко та інші). 
Діяльність розглядалась без участі суб'єкта, без врахування особистісних потреб і намірів учня і грунтувалась на ідеї зв'язку теорії з практикою. Як підкреслює 3 цього приводу К. Абульханова: «радянська ідеологія i філософія визначали на багато років лідерство «безсуб'єктивного» підходу: матерія - без людини, пізнання, діяльність, психіка - без суб'єкта. ... Акценти на структурі ... діяльності, ... відтіснили на задній план проблему їі суб'єкта» [1, с. 190-110].

3 іншого боку, ініціатива в досягненні певного освітнього результату у справі «безсуб’єктної» профорієнтації, покладалась виключно на активність самого учителя. Так, у більшості дисертаційних досліджень (80-90р. минулого століття ) обгрунтовується саме провідна роль учителя. Для прикладу, у дисертації «...ефективність професійної інформації зростає у тому випадку, коли учителі добре ознайомлені з потребами в кадрах, знають професіограми i формують професійну спрямованість в учнів, виходячи 3 виробничого оточення, застосовують більш прогресивні форми і методи» [10, с. 84-85]. Тобто учитель «все знає» i формує в учня професійну спрямованість, натомість роль учня відходить на другий план чи взагалі не береться до уваги. Діяльність учителя $є$ головною, учня - другорядною, він є об'єктом роботи учителя. Варто зауважити, що тенденція переоцінювання керівної ролі учителя i недооцінювання самостійності учня у навчанні, - це характерні риси радянської школи, які поширювались на всі напрямки загальноосвітньої підготовки i в тому числі, на завдання пов'язані із професійною орієнтацією учнівської молоді.

Примітно, що на практиці профорієнтаційна робота часто зводилась до заходів профорієнтаційного характеру. Зміст профорієнтації учнів у діяльнісному підході, як підкреслює М. Опачко, представлений у «...всій повноті функцій: провести, організувати, виступити, демонструвати, ознайомити, виконати тощо, тобто спрямований на профорієнтацію, як вид діяльності. Інтереси особистості, іiі бажання і потреби мали статус задекларованих понять». [5, с. 26].

У такий спосіб знецінювалась ідея профорієнтації. У зв'язку з цим Г. Костюк, вказуючи на психологічні особливості профорієнтаційної роботи iз старшокласниками наголошував про неприпустимість обходитись штучними чи показовими заходами загального характеру, тоді як профорієнтація, на думку ученого, $є$ справою виключно індивідуальною, $\mathrm{i}$ навіть інтимною: «Невдачі зазнає те виховання, яке зводиться до сукупності «заходів», зовнішньої дії на вихованців, ігнорує внутрішній світ його потреб, думок, почуттів...» [11, с. 16].

Отже, профорієнтація у загальноосвітній школі завжди була спрямована на «безсуб'єктну діяльність», у якій учень відігравав другорядну роль. Саме на вчителя покладалась роль свідомого і активного учасника учнівської профорієнтації. Учні залучались до вивчення політехнічних основ виробництва та продуктивної праці, і на цій основі їх ознайомлювали 3 
найбільш поширеними виробничими професіями. Диференціація трудової і професійної підготовки учнів у старшій школі не зменшувала обсяг знань 3 основ наук та предметів гуманітарного спрямування. Якщо у зарубіжному досвіді практичний (професійний) напрямок і науковий (академічний) були окремими, і вимоги до знань і вмінь учнів, що обирали ці напрямки, були також різними, то у радянській школі такого поділу не було, і в цілому вимоги до загальноосвітньої підготовки були орієнтовані на підготовку «усередненого» учня, який готовий до роботи на виробництві і водночас до вступу у вищий навчальний заклад для подальшої освіти. На справі виявлялось, що учні, які засвоювали певну професію не йшли на виробництво. Навіть засвоєння знань 3 основ наук підвищувало лише загальний рівень ерудиції, але не впливало на вибір майбутньої професії.

Зміщення акцентів у бік соціального замовлення і відрив від реальних потреб і запитів окремо взятої особистості з часом призвело до розриву між тією профорієнтаційною роботою, яку проводила школа, і тим до чого в дійсності готувались старшокласники (за допомогою репетиторів i матеріальних можливостей батьків) чи вибір який вони здійснювали. Досить часто залучення учнів до професійного вибору і власне професійна освіта виявлялись штучними і відірваними від життя випускників школи. Як відзначив $з$ цього приводу М. Шахмаєв «...спроба покласти на середню школу задачу професійної підготовки виявилась не дієздатною і призвела до ... недоліків у загальноосвітній підготовці випускників» [12, с. 286]. Протягом періоду існування радянської школи, всі їі випускники - після десятого класу - вступали до вищих закладів освіти. У той час (та й нині теж) випускники старшої школи були психологічно не готовими до праці на виробництві і у сфері обслуговування. Для них, і особливо для їхніх батьків, невдача із вступом до вузу - трагедія, а робота на виробництві - прикра необхідність. Склалось стійке уявлення, що повна середня освіта - це необхідна умова для одержання подальшої освіти. Причому причиною цього вважали (М. Скаткін, І. Лернер та інші) неосвіченість учнів про сучасне виробництво - «...це уявлення, засноване на ... не знанні сучасного виробництва, перейшло у забобони, мовляв свідоцтво про середню освіту путівка у вуз» [12]. Звідси й випливало основне завдання профорієнтації, спрямоване на засвоєння учням знань про сучасне виробництво, що намагались крім іншого реалізувати через «діяльнісний» підхід, поєднувати навчання 3 продуктивною працею тощо. «Школа, - підкреслював М. Шахмаєв, - має не лише роз'яснювати учням корисність і шляхетність будь-якої праці на користь суспільства, але й розкривати перед ними широкі можливості сучасного виробництва для творчого прикладення їхніх сил, знань і здібностей. Учні зобов'язані знати, що для оволодінням більшістю професій необхідна середня освіта» [Там само, с. 286]. I дійсно, в цілому можна погодитись, що школа зобов'язана виконувати вказані завдання інформувати учнів про світ професій, натомість не можна стверджувати, що це виведе роботу з профорієнтації на якісно новий рівень, оскільки вивчення 
політехнічних основ виробництва саме по собі не підвищує якість профорієнтаційної освіти - це завдання, яке намагались розв'язати з огляду на ідеологічні установки про керівну роль робітничого класу, що по суті й зводилось до популяризації робітничих професій через професійну агітацію. Однак нині встановлено, що перехід української освіти на профільне навчання підміняється розширенням «престижних» напрямків освіти, на тлі зменшення вибору технологічного і професійного профілів, що 3 одного боку свідчить про «традиційну» проблему, яка перейшла від радянської школи - масовість вищзої освіти, а 3 іншого є свідченням невідповідності між попитом і пропозицією на ринку праці. Також слід підкреслити, що крім відсутності наступності між старшою загальноосвітньою школою і вищою освітою, відсутнім є також зв'язок між системою вітчизняної освіти і ринку праці. Вказана проблема є актуальною для всіх національних систем освіти, колишнього Радянського Союзу. Як удало підкреслює з цього приводу Л. Нугуманова, «... роботодавця, який висуває вимоги до компетентності і який формує замовлення на фахівця, не турбує процес його підготовки. У цій ситуації стає проблематичним комплектування професійного кадрового потенціалу без додаткових затрат. Біржа праці як постачальник робочої сили, ... також має пасивну позицію 3 питань процесу підготовки фахівців. Достовірна інформація про потреби виробництва, про місце і роль людини не стають підставою для вибору професії старшокласниками» [13, с. 4].

Поінформованість учнів старшої школи про світ професій, як правило, є низькою, оскільки в основній школі не викладається окремий предмет 3 профорієнтації, за винятком трудової підготовки, де окремим розділом приділялась увага питанням вибору професії. Коли настає час вибору професії, учень залишається не підготовленим до такого вибору, крім знань про роботу батьків, провідними стають випадкові відомості, одержані від однолітків чи із засобів масової інформації. Оскільки «...сучасна педагогічна практика профільного навчання, як правило, не надає достатньо поширених прикладів формування ціннісних орієнтацій особистості учнів» [там само], то очевидно слід звернути увагу передовсім на особистість учня, його особистісні орієнтації та мотиви. Виховання учня до вмілого і своєчасного професійного вибору повинно здійснюватись у напрямку від потреб особистості, його родини, і вже потім орієнтуватись на потреби соціуму, враховувати реальні вимоги ринку праці.

Отже, важливим у професійній орієнтації є включення самої особистості, надання їй повної самостійності для самовизначення, що потребує перегляду питань, пов'язаних із саморегуляцією, самооцінюванням, професійною свідомістю. У зв’язку з цим сучасні дослідження науковців доводять, що для ефективного залучення учнів до вибору професії важливо встановити наступність між старшою школою і професійною освітою випускників і їхньою профільною підготовкою з урахуванням попиту і пропозиції на ринку праці, а також формування готовності учнів планувати власну професійну кар'єру. 
Висновки. Отже, нині є потреба у створенні таких педагогічних умов для проведення профорієнтаційної роботи, які б враховували позитивний досвід вітчизняної освіти і водночас, створювали у змісті профорієнтаційної роботи на будь-якому іiі рівні як цілісної системи, особистісний характер навчання. Діяльність за умов особистісно-орієнтованого підходу набуває іншої якості, оскільки відбиває не лише традиційні знання уміння і навички учнів, а й їх суб'єктивно-особистісний характер через мотивацію, оцінку, свідомість у практичній роботі і навчанні. Вказані умови знаходять своє відображення у змісті проектної діяльності учнів на уроках технології.

\section{Література}

1. Піддячий М. І. Організаційно-педагогічні умови підготовки старшокласників до професійного самовизначення у міжшкільних навчально-виробничих комбінатах / М.І. Піддячий : дисер. ... канд. пед. наук за спеціальністю 13.00 .07 - теорія і методика виховання - Інститут проблем виховання АПН України, К., 2002. - 220 с.

2. Васильєв В. В. Професійна адаптація молодих робітників в умовах формування ринкової економіки / В.В. Васильєв // Педагогіка і психологія. - 2000. - №1 - - С. 87-96.

3. Васильков В. М. Соціально-психологічні питання професійного самовизначення старшокласників у сучасних умовах / В.М. Васильков // Педагогіка і психологія. - 1999. №3. - С. 59-66.

4. Тхоржевський Д. О. Система трудового навчання / Д.О. Тхоржевський ; за ред. М. О. Жиделєва. - К. : Радянська школа, 1975. - 199 с.

5. Опачко М. В. Професійна орієнтація учнів у процесі розв'язування задач фізикотехнічного змісту / дисер. на здобуття наук ступеня канд. пед. наук // 13.00.02 - теорія і методика навчання фізики / М.В. Опачко. - Ужгород $-2001 .-255$ с.

6. Щекин Г. В. Теория кадровой политики: [монографія] / Г.В. Щекин. - К. : МАУП, 1997. - $176 \mathrm{c}$.

7. Бабанский Ю. К. Комплексный подход к воспитанию учащихся: (В вопросах и ответах) / Ю.Бабанский, Г.Победоносцев. - К. : Рад. школа, 1985. - 256 с.

8.Захаров Н. Н. Профессиональная ориентация школьников: [учеб. пособ. для студентов - слушателей фак. общ. профессий] / Н.Н. Захаров. - М.: Просвещение, 1988. - 272 с.

9. Абульханова К. О. Психология и сознание личности (Проблемы методологий, теорій и иследования реальной личности): [избранные пихологические труды] / К.О. Абульханова. - М. : Моск. псих.-соц. ин-т, Воронеж: Изд-тво НПО «МОДЭК», 1999. $-224 \mathrm{c}$.

10.Попыкин И. А. Педагогические условия повышения эффективности профориентационной работы с учащимися городских общеобразовательных школ: дисер.канд. пед. наук / И.А. Попыкин. - К. : 1984. - 230 с.

11.Костюк Г. С. Избранные психологические труды / Г.С. Костюк. - М. : Педагогика, 1988. - 304 с.

12.Дидактика средней школы / под ред. М. Н. Скаткина. - 2-е изд., перераб. и доп. М.: Просвещение, 1982. -319 с.

13.Нугуманова Л.Н. Профильно-ориентированное трудовое воспитание учащихся современной общеобразовательной школы : авторефер. дис. на соискание ченой степени док. пед. наук / Л.Н. Нугуманова. - Чебоксары, 2011. - 41 с.

Стаття надійшла до редакції 27.05.2012 p. 